\title{
Effects of habitat on settlement, growth, predation risk and survival of a temperate reef fish
}

\author{
M. Tupper ${ }^{1, *}$, R. G. Boutilier ${ }^{2}$ \\ Department of Biology, Dalhousie University, Halífax, Nova Scotia, Canada B3H 4J1 \\ ${ }^{2}$ Department of Zoology, University of Cambridge, Downing St., Cambridge CB2 3EJ, United Kingdom
}

\begin{abstract}
We rileasured adult density, settlement, post-settlement survival, recruitment success, predation risk and growth rate of the cunner Tautogolabrus adspersus in 4 distinct habitat types (rocky reef, cobble, seagrass and sand) in St. Margaret's Bay, Nova Scotia, Canada. Settlement was not affected by habitat type or by adult density. Post-settlement survival, recruitment success (defıned as the density of juveniles present after an arbitrary period following settlement) and adult density varied with habitat and were positively correlated with habitat complexity. This pattern was diametrically opposed to the pattern of predation risk, which was negatively correlated with habitat complexity. Growth of juvenile cunner differed between habitats but was unrelated to habitat complexity. Since the initial pattern of settlement was dramatically altered within a very short time, we concluded that habitat-mediated post-settlement processes play an important role in the population dynamics of cunner The results of this study demonstrate the importance of habitat in determining growth rates, rates of post-settlement mortality and recruitment success
\end{abstract}

KEY WORDS: Growth $\cdot$ Habitat $\cdot$ Mortality $\cdot$ Predation $\cdot$ Reef fish

\section{INTRODUCTION}

The majority of benthic and demersal marine organisms exhibit a bipartite life cycle with a dispersive larval phase followed by a relatively sedentary adult phase (Gaines \& Roughgarden 1985, Underwood \& Fairweather 1989, Hughes 1990, Sale 1991). Widespread dispersal and severe mortality of pelagic larvae serve to decouple local settlement of larvae into the adult habitat from the reproductive activity of the resident population (Doherty \& Fowler 1994). Settlement patterns derive from biological and physical processes operating on larvae during the transition from a pelagic to a benthic or demersal existence (Leis 1991. Kaufman et al. 1992). Local settlement strength is determined by the availability of larvae competent to settle. Larval supply may depend on large scale factors such as ocean current patterns or tides (Kingsford et al.

\footnotetext{
- Present address and address for correspondence: School of Marine Science, 5763 Rogers Hall, University of Maine, Orono, Maine 04469-5763, USA

E-mail: mtupper@apollo.umenfa.maine.edu
}

1991, Leis 1991, Shenker et al. 1993). Settlement is influenced on a smaller scale by microhabitat selection (Sale et al. 1984, Tolimieri 1995) or by the presence/ absence of certain resident organisms, particularly conspecifics (e.g. Sweatman 1988)

Mortality, movement and growth have been the most commonly studied post-settlement processes; all are capable of substantially modifying patterns of settlement and strongly influencing recruitment success (Jones 1990. Connell \& Jones 1991). Although early post-settlement mortality of reef fishes is known to be high (Shulman \& Ogden 1987, Sale \& Ferrell 1988, Connell \& Jones 1991), the magnitude and variability of mortality relative to settlement is unknown for most species (Connell \& Jones 1991), as is the mechanism behind this mortality. In general, mortality of newly settled fish is attributed to predation (Houde 1987). Indeed, Hixon (1991) and Hixon \& Beets (1989, 1993) suggest predation as a major factor structuring populations and communities of reef fishes. While several correlative studies (e.g. Shulman 1984, Carr \& Hixon 1995) have found negative relationships between predator abundance and prey fish abundance, few 
have attempted to measure predation on reef fishes directly (see Carr \& Hixon 1995).

Since the majority of studies of the population dynamics of reef fish have focused on small, sedentary taxa, movement (emigration and immigration) has not been considered a major factor in determining population size (Doherty 1983, Aldenhoven 1986, Connell \& Jones 1991). While many species display strong site fidelity, others may move relatively large distances (Robertson 1988a, Forrester 1990) Movement may occur in response to intense competition (densitydependent emigration), or in response to ontogenetic shifts in habitat requirements (Shulman \& Ogden 1987). Relocation of juvenile or adult fish will tend to decouple adult numbers from settlement in a given area (Robertson 1988a, b)

Growth has also received increasing attention as a factor critically important to the demography of juvenile and adult fishes (Jones 1986, 1987, 1990. Forrester 1990, Connell \& Jones 1991, Sogard 1992). Growth may influence adult population size directly, by controlling the number of individuals reaching reproductive maturity (Jones 1987, 1991), or indirectly, through the effects of size-selective mortality on juvenile survival (Forrester 1990, Sogard 1992). Rapid growth means less time spent in the smaller, potentially more vulnerable size classes (Post \& Evans 1989). In temperate reef fishes, rapid growth may confer an additional, physiological advantage, since overwinter survival is generally higher in larger individuals (Henderson et al. 1988). Growth of juvenile fishes can be limited by food supply (Jones 1986, 1987, Forrester 1990, Sogard 1992) or regulated by hierarchical social inhibition (Forrester 1990, Tupper \& Boutilier 1995a, b).

Many species of demersal and reef fishes occur in a wide range of habitats. Settlement and post-settlement demography of these species may be affected by structural characteristics of the habitat (Carr 1989, 1991, 1994, Connell \& Jones 1991, Levin 1991). Habitat structure has been implicated in the determination of settlement (Sale et al. 1984. Tolimieri 1995), post-settlement mortality (Shulman. 1984, Behrents 1987, Sogard 1992, Levin 1993), movement (Robertson 1988a,b) and growth (Jones 1986, Sogard 1992). Many studies have found the distribution and abundance of fishes to be correlated with the amount and type of available habitat (Shulman 1984, 1985, Connell \& Jones 1991, Levin 1991, 1993, Sogard 1992, Carr 1994, Tupper \& Boutilier 1995c). Characteristics of habitat that are known to influence population size include depth (Thresher 1983), reef size (Shulman 1984), reef isolation (Walsh 1985), vertical relief (Thresher 1983, Chandler et al. 1985), coral or vegetation cover (Bell \& Galzin 1984, Levin 1991), and topographic complexity (Luckhurst \& Luckhurst 1977. Chandler et al. 1985,
Roberts \& Ormond 1987, Connell \& Jones 1991, Booth and Beretta 1994). Of these, topographic complexity has perhaps the greatest influence on post-settlement processes. A more complex habitat may offer more shelter, resulting in reduced predation pressure (Behrents 1987, Connell \& Jones 1991, Tupper \& Boutilier 1995c). Several researchers have shown survivorship of newly settled fishes to be strongly influenced by the availability of refuge sites, particularly in the presence of predators and/or conspecifics (Shulman 1984, 1985, Behrents 1987, Hixon \& Beets 1989, Carr 1991, 1994, Connell \& Jones 1991, Tupper \& Boutilier 1995c). Habitat complexity may also influence growth and survival through increased prey density and diversity (Holbrook \& Schmitt 1988, Connell \& Jones 1991 , Sogard 1992).

While selection of microhabitat at settlement is well documented (Jones 1984, Sale et al. 1984, Eckert 1985. Breitburg 1989, 1991, Levin 1993, Tolimieri 1995), the importance of habitat structure to post-settlement processes has only recently been established (Carr 1994, Tupper \& Boutilier 1995c). For most species it is unknown whether habitat structure determines patterns of settlement, and whether post-settlement processes alter or reinforce patterns of settlement (Jones 1990, Booth \& Beretta 1994). This study examines the influence of habitat on settlement, growth and post-settlement mortality of the temperate labrid Tautogolabrus adspersus. We use mark-recapture techniques to quantify movement and mortality of newly settled fish, and to measure individual growth rates. In order to determine the role of predation in determining post-settlement mortality, we measured predator density and capture success in different habitats. We then attempted to relate patterns of early survivorship to patterns of growth and predation, and to determine the relative influence of settlement and post-settlement processes on the recruitment success [operationally defined as the density of newly settled $(0+)$ fish surviving for an arbitrary period following settlement; see Levin 1993] of T. adspersus.

\section{METHODS}

Species and study sites. The cunner Tautogolabrus adspersus is a common nearshore species ranging from Conception Bay, Newfoundland, Canada, south to New Jersey, USA (Scott \& Scott 1988). Cunner occur from the intertidal zone (Whoriskey 1983) to depths of nearly $100 \mathrm{~m}$ on the offshore banks (Scott \& Scott 1988). Along the Atlantic coast of Nova Scotia and in the Gulf of Maine, cunner spawn mainly in late July and August; settlement occurs about 3 wk later and is restricted to a period 3 to $4 \mathrm{wk}$ in length (Levin 1.991, 
1993, 1994a). After settlement, cunner remain tenaciously site-attached for the first 1 to $2 y$ r of demersal life (Tupper 1994). Newly settled cunner appear to feed opportunistically on zooplankton and small benthic invertebrates, but prefer amphipods and isopods (Chao 1972, Levin 1994b). Cunner are found in a wide variety of habitats, but are generally associated with structure, including macroalgae (Levin 1991), rocky reefs, wrecks and pilings (Scott \& Scott 1988). Cunner are active by day, but enter a period of torpor at night. During this time they shelter under rocks, in crevices, or among vegetation (Dew 1976). If suitable shelter is not available, cunner will adopt a banded colour and lie in a torpid state on open bottom (authors' pers. obs.). While the banded colour may offer some camouflage, dormant cunner on exposed bottom are likely to be at greater risk of predation than their sheltered counterparts.

The study was conducted in St. Margaret's Bay, Nova Scotia, Canada, and was replicated at 3 sites. The nearshore bottom of St. Margaret's Bay can be divided into 4 broad habitat types: rocky reef (characterized by bedrock strewn with large granitic boulders), cobble bottom, seagrass (Zostera marina) beds, and sand bottom. All habitat types were represented at each of the 3 sites. At each site, four $10 \mathrm{~m}$ replicate transect lines were laid in each of the 4 habitat types. All transects were within $100 \mathrm{~m}$ of shore, at a depth of 1.5 to $2 \mathrm{~m}$ (mean low tide). Settlement, resident densities, growth rates, and predation rates were assessed in reef, cobble, grass, and sand habitats at each site, using a 3 -factor ( 3 sites $\times 4$ habitats $\times 2$ yr) experimental design. The substrate rugosity (a measure of habitat complexity; see Chandler et al. 1985) of each transect site was estimated by fitting a fine-link brass chain to the bottom contours along the transect line. The total distance covered by the chain was then divided by $10 \mathrm{~m}$ (the horizontal distance covered by the transect line), producing an index of substrate rugosity. It is important to note that substrate rugosity is simply a measure of the actual surface area of bottom structure available to an organism and does not account for other possible shelter sites, such as that provided by macroalgae or seagrasses. The association of newly settled fish with macroalgae has been well documented for cunner in the Gulf of Maine, USA (Levin 1991, 1994b). However, at the sites in St. Margaret's Bay, intense grazing by the sea urchin Strongylocentrotus drobachiensis reduced algal cover on reefs and cobble bottoms to a short filamentous turf. Within seagrass beds, young-of-year cunner were always observed in association with scattered rocks, debris, and empty scallop shells (Placopecten magellanicus). This suggests that at these sites, vegetation is less important in providing shelter than the physical structure of the bottom per se.
Census techniques. Visual censuses of total abundance of cunner were conducted at roughly $10 \mathrm{~d}$ intervals from July 1 to November 6, 1991, and from July 7 to November 9, 1992, by snorkeling slowly along the transect lines and counting all individuals within $1 \mathrm{~m}$ of either side of the transect line $\left(20 \mathrm{~m}^{2}\right.$ planar surface area). During the settlement season (mid-August to early September), newly settled cunner were collected daily from each transect. Cunner were captured using a $10 \%$ solution of Quinaldine in seawater and were placed in a polyethylene bag containing seawater. A separate bag was used for each transect. When all newly settled cunner had been removed from all 4 transects in a given site-habitat combination, the fish were brought to shore, their length measured to the nearest $\mathrm{mm}$ with a $100 \mathrm{~mm}$ plastic ruler, and marked with injections of acrylic paint, using a specific pattern of colours and dots to identify individuals. The marked fish were then returned to the transect from which they were captured. Fish were released individually along the length of the transect, always near a crevice or other form of shelter. Wherever possible, individuals were returned to the exact point of capture. At each point of release, a small lead disk bearing the same pattern of coloured dots as the released fish was affixed to the substrate. This procedure allowed marked individuals to be recognized as prior residents in subsequent censuses, and allowed quantification of growth, mortality and movement at each site. On 3 occasions during the study, censuses were conducted of the area $10 \mathrm{~m}$ on either side of the transect line. The presence of marked fish at distances of $2 \mathrm{~m}$ or more from the transect line would be considered evidence of emigration.

To determine the handling effects of the capture and marking technique, a group of $1500+$ cunner were captured and held in $500 \mathrm{l}$ aquaria in a laboratory. After a 1 mo acclimation period, the fish were subjected to the same capture and marking technique used in the field. One month after the procedure, 144 of 150 fish remained alive, i.e. mortality due to handling was $4 \%$. We therefore concluded that handling had little effect on the in situ mortality of cunner in this experiment. The extremely low mortality attributed to the marking technique resulted both from the hardiness of this species and from the amount of practice gained over the course of several studies on cunner (Tupper 1994, Tupper \& Boutilier 1995b); over 2000 cunner were tagged in this manner by the authors in the 2 years preceding this study.

Continuous water temperature records were not available for the specific study sites, but were available from an aquaculture site at the head of St. Margaret's Bay, approximately $2 \mathrm{~km}$ from the study sites. Water temperatures on each transect were recorded immedi- 
ately following a census with a mercury thermometer held at the substrate-water interface. On any day throughout the study, there was less than $1^{\circ} \mathrm{C}$ difference in temperature between locations and between transect sites at a location. It was therefore assumed that differences in population density or growth among habitats or locations were not attributable to spatial variations in temperature. The general uniformity of temperature across the lower reaches of St. Margaret's Bay is most likely due to regular tidal flushing

Predation. It would be impossible to directly measure the rate of predation and proportion of mortality attributable to predation without $24 \mathrm{~h}$ surveillance throughout the entire settlement and post-settlement period. Instead, we compared spatial patterns of predator density and predator success to spatial patterns of juvenile survivorship and post-recruitment density, to determine if post-recruitment demography could be explaincd by variation in predation. At each transect site, observations of predation by other fishes on young-of-year cunner were made in situ. Observations were conducted in September of 1991 and 1992. The observer floated motionless above the site while recording the species and number of predators, the number of attempted strikes (lunges at a cunner) and the number of successful strikes (capture and ingestion of a cunner) over a 1 h observation period on each transect (i.e. $12 \mathrm{~h}$ of observation per habitat per year). An index of predator success was then calculated by dividing the number of successful strikes by the total number of strikes, for each of the 4 habitat types. Mean predator success in each habitat was calculated as the average predator success over the 12 transects ( 4 transects per habitat at each of 3 sites). It is possible that tagging increased the visibility of $0+$ cunner leading to artificially increased predation and mortality. However, since all $0+$ cunner on the transects were tagged at the time of the predation study, we cannot comment on the relative vulnerability of tagged versus untagged individuals to predation.

Data analysis. An exploratory 2 -way analysis of variance (ANOVA) indicated that mean substrate rugosity (measured for each habitat type as the average of the 12 transects) differed significantly among all of the 4 habitat types $(F=2.37$, p $<0.05$; Tukey's HSD, $\mathrm{p}<0.05$ for all pairwise comparisons), but not among sites ( $F=$ $0.08, p>0.05$ ). No significant interaction between site and habitat was detected. We are therefore confident that the 4 habitat types chosen represent real differences in terms of the amount of shelter available to newly settled cunner.

Adult density, settlement, juvenile survivorship, recruitment success (density of $0+$ cunner remaining in November, approximately $8 \mathrm{wk}$ after the end of the settlement season), and growth rate were compared within and among sites, habitats and years using 3-way ANOVA (Snedecor \& Cochran 1981). Predator densities and capture success rates were compared among sites, habitats and years using the same analytical procedure. In order to determine where significant differences between years, or among sites or habitats occurred, post-hoc analyses were conducted using Tukey's HSD (Snedecor \& Cochran 1981). All numeric data were tested for homogeneity of variance using Bartlett's test, and $\log (x+1)$ transformed where necessary to ensure homoscedasticity (Snedecor \& Cochran 1981). Substrate rugosity, survivorship and capture success data were expressed as proportions and were therefore arcsine-square-root transformed prior to analysis. However, transformation failed to normalize substrate rugosity data. The influence of substrate rugosity on demographic variables was therefore analyzed using Spearman's rank correlation.

\section{RESULTS}

\section{Adult distribution and abundance}

Population density of adult cunner varied significantly among habitats (ANOVA, $F=613.5, p<0.001$; Table 1), but did not differ between years $(F=0.15, \mathrm{p}=$ $0.70)$ or among sites $(F=1.40, \mathrm{p}=0.25)$. Post-hoc tests (Tukey's HSD) indicated that all pairwise comparisons of habitats were significantly different $(p<0.05)$ except

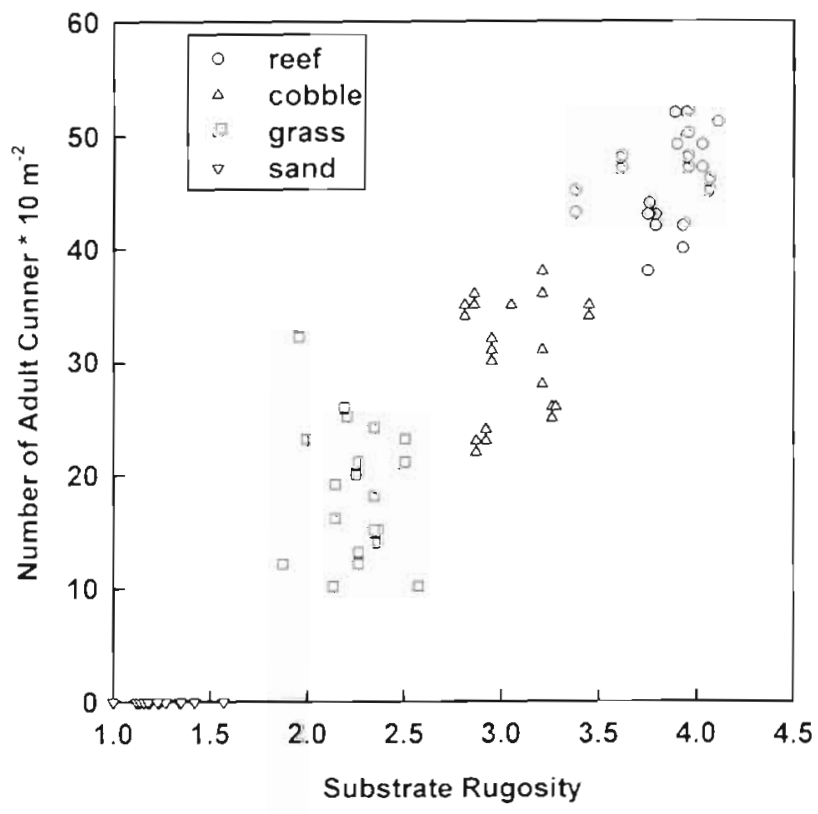

Fig. 1 Tautogolabrus adspersus. Effects of substrate rugosity on population density of adult cunner in St. Margaret's Bay. Nova Scotia. Data are from censuses conducted at $10 \mathrm{~d}$ intervals from July to November, 1991 and 1992 
Table 1. Tautogolabrus adspersus. Means and standard deviations for density of adults (number per transect), cumulative settlement per transect, post-recruitment density (recruitment success) and percent juvenile survival in St. Margaret's Bay, Nova Scotia

\begin{tabular}{|c|c|c|c|c|c|c|}
\hline Year & Site & Habitat & $\begin{array}{l}\text { Adult } \\
\text { density }\end{array}$ & $\begin{array}{c}\text { Total } \\
\text { settlement }\end{array}$ & $\begin{array}{l}\text { Recruitment } \\
\text { success }\end{array}$ & $\begin{array}{l}\text { Percent } \\
\text { survival }\end{array}$ \\
\hline \multirow[t]{12}{*}{1991} & Back Cove & Reef & $47.5 \pm 2.65$ & $160 \pm 24.5$ & $6.5 \pm 0.58$ & $4.2 \pm 0.91$ \\
\hline & & Cobble & $34.3 \pm 1.71$ & $140 \pm 14.1$ & $4.0 \pm 0.82$ & $2.9 \pm 0.87$ \\
\hline & & Grass & $12.0 \pm 2.45$ & $153 \pm 18.9$ & $1.5 \pm 0.58$ & $1.0 \pm 0.41$ \\
\hline & & Sand & $0.00 \pm 0.00$ & $143 \pm 5.00$ & $0.0 \pm 0.00$ & $0.0 \pm 0.00$ \\
\hline & Birch Head & Reef & $46.0 \pm 3.83$ & $142 \pm 20.6$ & $5.8 \pm 0.96$ & $4.1 \pm 0.54$ \\
\hline & & Cobble & $28.5 \pm 4.43$ & $148 \pm 20.6$ & $4.3 \pm 0.50$ & $3.1 \pm 0.42$ \\
\hline & & Grass & $21.8 \pm 7.27$ & $141 \pm 21.6$ & $1.8 \pm 0.50$ & $1.2 \pm 0.31$ \\
\hline & & Sand & $0.00 \pm 0.00$ & $145 \pm 30.0$ & $0.0 \pm 0.00$ & $0.0 \pm 0.00$ \\
\hline & Mill Cove & Reef & $43.0 \pm 3.92$ & $152 \pm 9.60$ & $5.5 \pm 0.58$ & $3.6 \pm 0.39$ \\
\hline & & Cobble & $26.3 \pm 3.69$ & $163 \pm 19.6$ & $3.8 \pm 0.50$ & $2.5 \pm 0.39$ \\
\hline & & Grass & $22.3 \pm 3.50$ & $155 \pm 31.1$ & $1.5 \pm 0.58$ & $0.9 \pm 0.35$ \\
\hline & & Sand & $0.00 \pm 0.00$ & $150 \pm 24.5$ & $0.0 \pm 0.00$ & $0.0 \pm 0.00$ \\
\hline \multirow[t]{12}{*}{1992} & Back Cove & Reef & $49.0+4.24$ & $16.3 \pm 22.2$ & $7.5 \pm 1.29$ & $4.6 \pm 0.78$ \\
\hline & & Cobble & $35.0 \pm 2.45$ & $158 \pm 15.0$ & $6.3 \pm 0.96$ & $4.0 \pm 0.55$ \\
\hline & & Grass & $12.3 \pm 2.06$ & $147 \pm 15.0$ & $3.5 \pm 0.58$ & $2.4 \pm 0.42$ \\
\hline & & Sand & $0.00 \pm 0.00$ & $145 \pm 12.9$ & $0.0 \pm 0.00$ & $0.0 \pm 0.00$ \\
\hline & Birch Head & Reef & $46.5 \pm 3.87$ & $148 \pm 15.0$ & $7.3 \pm 0.96$ & $4.9 \pm 0.46$ \\
\hline & & Cobble & $28.8 \pm 5.32$ & $150 \pm 14.1$ & $6.0 \pm 0.82$ & $4.0 \pm 0.69$ \\
\hline & & Grass & $21.3 \pm 8.14$ & $163 \pm 17.1$ & $3.3 \pm 0.50$ & $2.1 \pm 0.56$ \\
\hline & & Sand & $0.00 \pm 0.00$ & $148 \pm 20.6$ & $0.0 \pm 0.00$ & $0.0 \pm 0.00$ \\
\hline & Mill Cove & Reef & $44.3 \pm 3.50$ & $147 \pm 15.0$ & $7.5 \pm 1.29$ & $5.1 \pm 0.41$ \\
\hline & & Cobble & $27.8 \pm 5.25$ & $147 \pm 20.6$ & $6.0 \pm 0.50$ & $4.1 \pm 0.38$ \\
\hline & & Grass & $21.5 \pm 3.11$ & $148 \pm 20.6$ & $3.0 \pm 0.82$ & $2.4 \pm 0.54$ \\
\hline & & Sand & $0.00 \pm 0.00$ & $166 \pm 17.3$ & $0.0 \pm 0.00$ & $0.0 \pm 0.00$ \\
\hline
\end{tabular}

reef and cobble. Adult (age 1+ and older) cunner were most abundant on reefs, followed by cobble and then grass habitats, and were absent from sand bottom in all censuses. In both 1991 and 1992, adult density was significantly correlated with substrate rugosity (Spearman's rank correlation, $r_{S}=0.81, p<0.001$ and $r_{S}=$ $0.88, p<0.001$, respectively; Fig. 1).

\section{Settlement}

Mean cumulative settlement of cunner over the settlement season in 1991 and 1992 is shown in Table 1. No significant effect of year $(F=0.58, \mathrm{p}=0.45)$, site $(F=$ $0.97, \mathrm{p}=0.38)$, or habitat $(F=0.48, \mathrm{p}=0.70)$ on settlement strength were detected by ANOVA. This suggests that cunner did not actively select microhabitats at settlement, but settled in a rather uniform distribution throughout the nearshore waters of St. Margaret's Bay.

\section{Juvenile survivorship and recruitment success}

Post-settlement survival (over a period of 3 mo) of $0+$ cunner ranged from $0 \%$ on sand bottoms to approximately $4.5 \%$ in reef habitats (Table 1 ). The decline in
$0+$ cunner population density was attributed to postsettlement mortality rather than emigration, since unmarked $0+$ cunner were never observed on the transects, suggesting that movement of $0+$ cunner is limited. Moreover, on 3 occasions, censuses were conducted of the area $10 \mathrm{~m}$ either side of each transect line (200 $\mathrm{m}^{2}$ total area). These censuses failed to reveal the presence of any marked individuals. However, newly settled cunner disappeared so rapidly from sand transects that emigration may have played a role in population loss from this habitat.

Survival of newly settled cunner varied widely among habitats (ANOVA, $F=471.0, p<0.001$ ), but did not differ among sites $(F=0.36, \mathrm{p}=0.14)$. In pairwise multiple comparisons, only reef and cobble showed no significant difference in survival of $0+$ cunner (Tukey's HSD, $p<0.05$ for all pairwise comparisons except reef versus cobble) In most habitats, survival was significantly higher in 1992 than in 1991 ( $F=95.4, p<0.001)$. Survival of newly settled cunner increased with increasing substrate rugosity (Fig. 2A) in 1991 ( $\mathrm{r}_{\mathrm{S}}=$ $0.82, p<0.001$ ) and in $1992\left(r_{S}=0.76, p<0.001\right)$.

Among-habitat comparisons of recruitment success (number of $0+$ cunner remaining in November) revealed significant differences among habitat types (ANOVA, $F=$ $444.2, p<0.001$ ). Recruitment was highest on rocky reefs, 

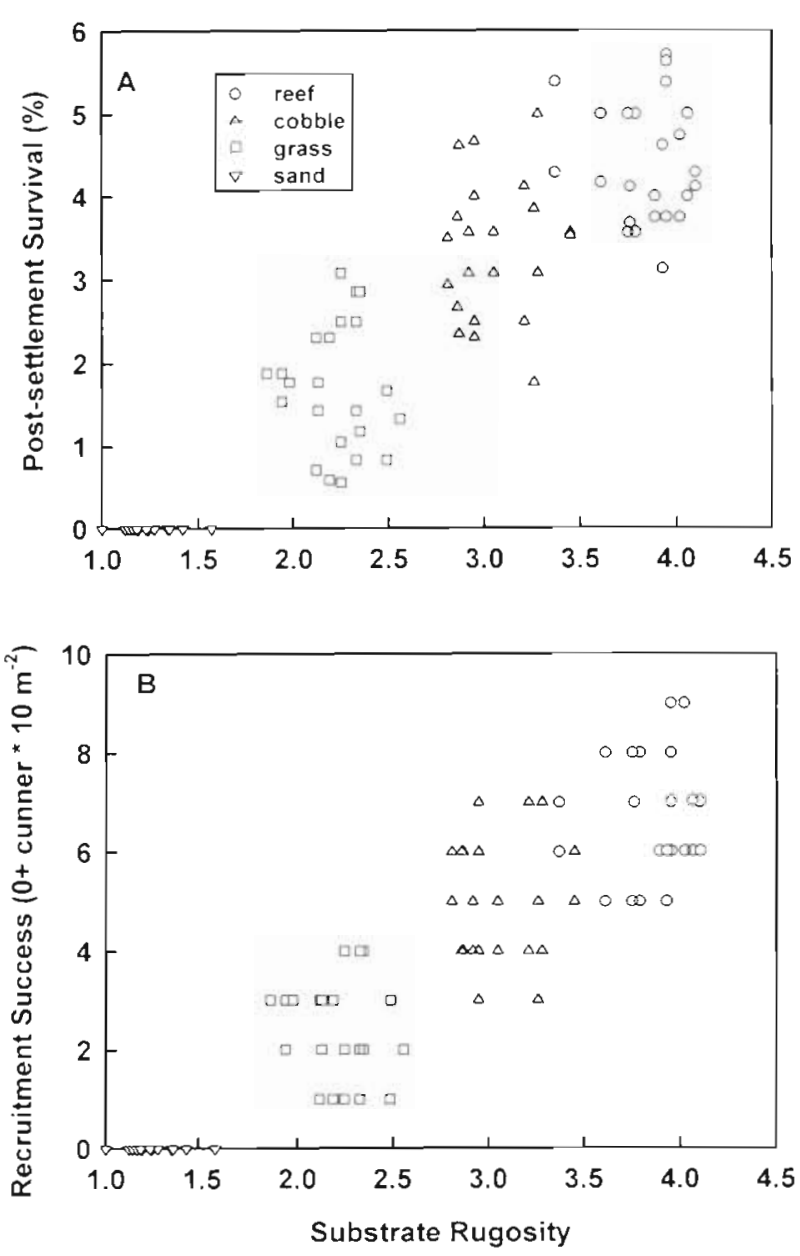

Fig. 2. Tautogolabrus adspersus. Effects of substrate rugosity on (A) post-settlement survival and (B) recruitment success (number of $0+$ cunner remaining on a transect at the end of November) in St. Margaret's Bay, Nova Scotia. Survival was estimated for each transect as the number of $0+$ cunner remaining in November (i.e. recruitment success) divided by the total number of cunner that settled on that transect

followed by cobble and then seagrass beds (Table 1). This pattern suggests that Zostera marina blades are not suitable refuges for newly settled cunner. As with survival, recruitment success was zero on sand habitats. Recruitment did not differ among sites $(F=0.14, \mathrm{p}=0.87$ ), but was significantly higher in 1992 than in 1991 ( $F=$ $8.79, p=0.004)$. Correlation analysis revealed a strong. positive relationship between the substrate rugosity of a transect site and recruitment success (Fig. 2B) in 1991 $\left(r_{S}=0.95, p<0.001\right)$ and in $1994\left(r_{S}=0.94, p<0.001\right)$.

In summary, despite a uniform pattern of settlement among habitats and sites, recruitment success varied significantly with rugosity and was higher in more complex habitats. The pattern of post-recruitment juvenile distribution among transects was identical to the pattern of adult distribution.

\section{Predation on juvenile cunner}

Three species of the family Cottidae (Hemitripterus americanus, Myoxocephalus actodecemspinosus and Myoxocephalus aeneus) were observed preying on juvenile cunner during this study. Since these 3 species are confamilials with very similar behaviours, they were pooled together as 'cottid predators'. Total density of cottid predators (Table 2) did not vary among habitats (ANOVA, $F=0.26, p=0.85$ ) or sites $(F=1.00$, $\mathrm{p}=0.37)$ or between years $(F=0.02, \mathrm{p}=0.88)$,

A total of 299 and 241 predator-prey interactions (attempted captures) were observed in 1991 and 1992, respectively. The number of strikes observed per hour (Table 2) was significantly higher in 1991 than 1992 (ANOVA, $F=3.53, p=0.04$ ), but did not vary among sites $(F=0.38, \mathrm{p}=0.68)$ or habitats $(F=0.68, \mathrm{p}=0.57)$. Capture success varied significantly among habitats (ANOVA, $F=364.9 . \mathrm{p}<0.001$ ), but also did not differ among sites $(F=2.11, p=0.36)$ or between years $(F=$ $0.02, p=0.54$ ). Predators were most efficient on open sand bottoms and least efficient in reef and cobble habitats (Table 2), only reef and cobble bottoms did not differ in capture success (Tukey's HSD, $p<0.05$ for all pairwise comparisons except reef versus cobble). The fact that capture success was higher in seagrass beds than on reefs or cobble bottoms again suggests that this type of vegetation does not provide optimal shelter for small cunner Capture success was inversely related to substrate rugosity $\left(r_{S}=-0.86, p<0.001\right.$ for $1991 ; r_{S}=-0.88, p<0.001$ for 1992; Fig. 3), juvenile sur vivorship $\left(r_{S}=-0.92, p<0.001\right.$ for $1991 ; r_{S}=-0.81, p<$ 0.001 for 1992; Fig, 4A) and recruitment success $\left(r_{S}=\right.$ $-0.92, p<0.001$ for $1991 ; r_{S}=-0.83, p<0.001$ for 1992 ; Fig. 4B). These results suggest that predation strongly influences juvenile survivorship and subsequent postrecruitment demographics of cunner.

\section{Growth}

A total of 83 marked recruits were recovered and remeasured in November 1991; 73 were recovered in November 1992. The extreme mortality (or rapid emigration) suftered on sand bottom made it impossible to measure growth in this habitat. At all 3 sites, and in both years, growth rate of newly settled cunner was highest in seagrass beds (ANOVA, $F=101.2, p<0.001$; Table 3). Growth rates on reef and cobble bottoms were not significantly different (Tukey's HSD, p > $0.05)$. Growth rates did not vary significantly between years $(F=0.71, \mathrm{p}=0.75)$ or among sites $(F=0.38, \mathrm{p}=$ $0.58)$. Growth was not related to substrate rugosity in $1991\left(r_{S}=0.0, p=0.75\right)$ or $1992\left(r_{S}=0.0, p=0.70\right)$, but may have been influenced by increased prey density 
Table 2. Means and standard deviations for density of coltid predators (number per transect), number of attempted strikes per hour, number of captures per hour and percent capture success in St. Margaret's Bay, Nova Scotia

\begin{tabular}{|c|c|c|c|c|c|c|}
\hline Year & Site & Habitat & $\begin{array}{l}\text { Predator } \\
\text { density }\end{array}$ & $\begin{array}{c}\text { No. of strikes } \\
\mathrm{h}^{-1}\end{array}$ & Captures $\mathrm{h}^{-1}$ & $\begin{array}{l}\text { Capture } \\
\text { success }\end{array}$ \\
\hline \multirow[t]{12}{*}{1991} & Back Cove & Reef & $1.13 \pm 0.31$ & $6.19 \pm 1.77$ & $1.20 \pm 0.48$ & $0.19 \pm 0.04$ \\
\hline & & Cobble & $1.18 \pm 0.28$ & $5.06 \pm 0.72$ & $1.13 \pm 0.47$ & $0.26 \pm 0.06$ \\
\hline & & Grass & $0.90 \pm 0.14$ & $6.94 \pm 1.13$ & $2.82 \pm 0.57$ & $0.41 \pm 0.07$ \\
\hline & & Sand & $0.93 \pm 0.26$ & $5.44 \pm 1.42$ & $3.13 \pm 0.59$ & $0.59 \pm 0.14$ \\
\hline & Birch Head & Reef & $1.25 \pm 0.24$ & $6.56 \pm 1.66$ & $1.24 \pm 0.58$ & $0.19 \pm 0.05$ \\
\hline & & Cobble & $1.10 \pm 0.36$ & $6.94 \pm 1.13$ & $1.84 \pm 0.74$ & $0.26 \pm 0.07$ \\
\hline & & Grass & $0.98 \pm 0.22$ & $5.63 \pm 1.44$ & $2.65 \pm 0.90$ & $0.46 \pm 0.05$ \\
\hline & & Sand & $1.00 \pm 0.18$ & $5.63 \pm 0.43$ & $3.81 \pm 0.76$ & $0.68 \pm 0.13$ \\
\hline & Mill Cove & Reef & $0.98 \pm 0.34$ & $6.56 \pm 1.66$ & $1.20 \pm 0.21$ & $0.19 \pm 0.03$ \\
\hline & & Cobble & $1.00 \pm 0.26$ & $4.88 \pm 3.27$ & $1.43 \pm 1.12$ & $0.28 \pm 0.04$ \\
\hline & & Grass & $1.25 \pm 0.24$ & $8.44 \pm 1.66$ & $4.27 \pm 1.69$ & $0.50 \pm 0.12$ \\
\hline & & Sand & $1.03 \pm 0.46$ & $6.38 \pm 1.98$ & $4.26 \pm 1.31$ & $0.70 \pm 0.06$ \\
\hline \multirow[t]{12}{*}{1992} & Back Cove & Reef & $1.15 \pm 0.37$ & $6.56 \pm 1.66$ & $0.91 \pm 0.23$ & $0.16 \pm 0.02$ \\
\hline & & Cobble & $1.13 \pm 0.31$ & $4.50 \pm 1.62$ & $1.88 \pm 0.99$ & $0.28 \pm 0.09$ \\
\hline & & Grass & $1.03 \pm 0.30$ & $4.50 \pm 1.62$ & $1.91 \pm 0.69$ & $0.43 \pm 0.05$ \\
\hline & & Sand & $1.38 \pm 0.10$ & $5.44 \pm 0.72$ & $3.88 \pm 0.75$ & $0.72 \pm 0.05$ \\
\hline & Birch Head & Reef & $1.00 \pm 0.47$ & $6.00 \pm 2.67$ & $1.09 \pm 0.52$ & $0.18 \pm 0.02$ \\
\hline & & Cobble & $0.93 \pm 0.26$ & $4.69 \pm 0.97$ & $1.11 \pm 0.30$ & $0.24 \pm 0.03$ \\
\hline & & Grass & $1.10 \pm 0.29$ & $3.00 \pm 2.48$ & $1.31 \pm 1.03$ & $0.43 \pm 0.08$ \\
\hline & & Sand & $1.03 \pm 0.22$ & $3.00 \pm 2.90$ & $2.13 \pm 2.12$ & $0.67 \pm 0.06$ \\
\hline & Mill Cove & Reef & $1.08 \pm 0.33$ & $4.50 \pm 1.37$ & $0.77 \pm 0.39$ & $0.17 \pm 0.02$ \\
\hline & & Cobble & $1.13 \pm 0.31$ & $4.88 \pm 3.27$ & $1.42 \pm 1.14$ & $0.28 \pm 0.07$ \\
\hline & & Grass & $1.13 \pm 0.39$ & $6.56 \pm 2.24$ & $2.59 \pm 0.72$ & $0.41 \pm 0.07$ \\
\hline & & Sand & $1.18 \pm 0.22$ & $5.81 \pm 1.28$ & $3.53 \pm 1.49$ & $0.64 \pm 0.14$ \\
\hline
\end{tabular}

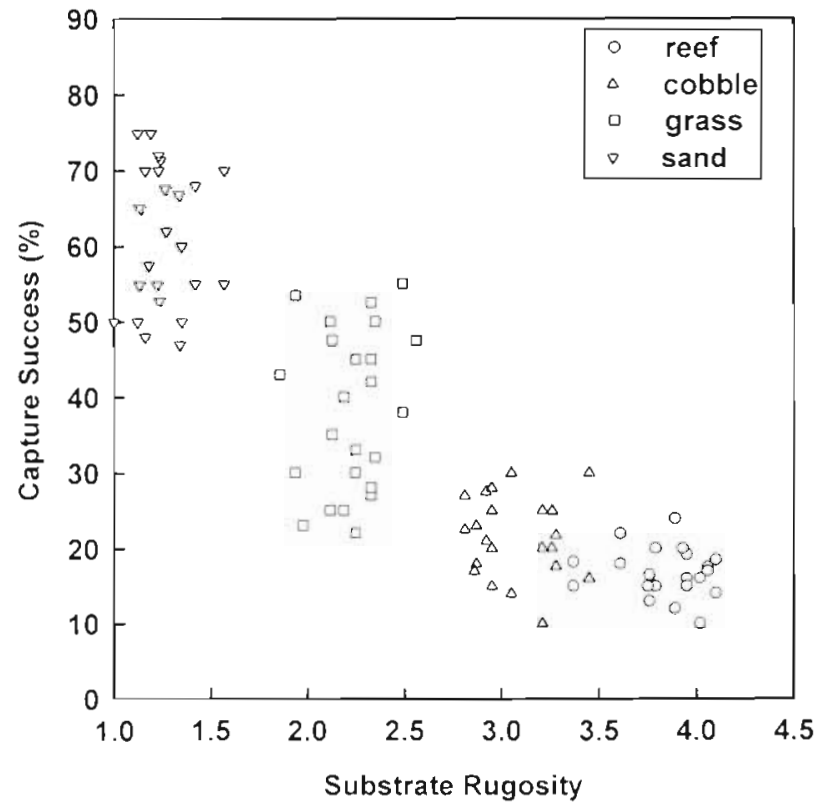

Fig. 3. Tautogolabrus adspersus. Effects of substrate rugosity on capture success of cottid predators Hemitripterus americanus, Myoxocephalus octodecemspinosus and $M$ aeneus feeding on $0+$ cunner. Capture success was calculated as the number of successful captures by a cottid predator divided by the total number of attempted captures
Table 3. Tautogolabrus adspersus. Means and standard deviations for growth of individually tagged $0+$ cunner in St. Margaret's Bay, Nova Scotia. 'Significantly different from other habitats

\begin{tabular}{|lllc|}
\hline \multirow{2}{*}{ Site } & Habitat & \multicolumn{2}{c|}{ Growth rate $\left(\mathrm{mm} \mathrm{d}^{-1}\right)$} \\
& & 1991 & 1992 \\
\hline \multirow{2}{*}{ Back Cove } & Reef & $0.47 \pm 0.04$ & $0.46 \pm 0.03$ \\
& Cobble & $0.47 \pm 0.03$ & $0.48 \pm 0.03$ \\
& Grass & $0.54 \pm 0.02^{\circ}$ & $0.55 \pm 0.02$ \\
Birch Head & Reef & $0.46 \pm 0.03$ & $0.47 \pm 0.03$ \\
& Cobble & $0.47 \pm 0.03$ & $0.45 \pm 0.03$ \\
& Grass & $0.53 \pm 0.04^{*}$ & $0.54 \pm 0.04^{\circ}$ \\
Mill Cove & Reef & $0.48 \pm 0.03$ & $0.44 \pm 0.02$ \\
& Cobble & $0.45 \pm 0.03$ & $0.46 \pm 0.03$ \\
& Grass & $0.56 \pm 0.02$ & $0.56 \pm 0.03 \cdot$ \\
& & & \\
\hline
\end{tabular}

in seagrass habitats (see Sogard 1992). The spatial pattern of variation in growth rate was unrelated to patterns of post-recruitment juvenile and adult densities, suggesting that population density had little effect on growth, at least at the levels encountered in this study. However, since population density in a given habitat did not differ among sites, we cannot comment on the effects of population density on growth in a particular habitat. 

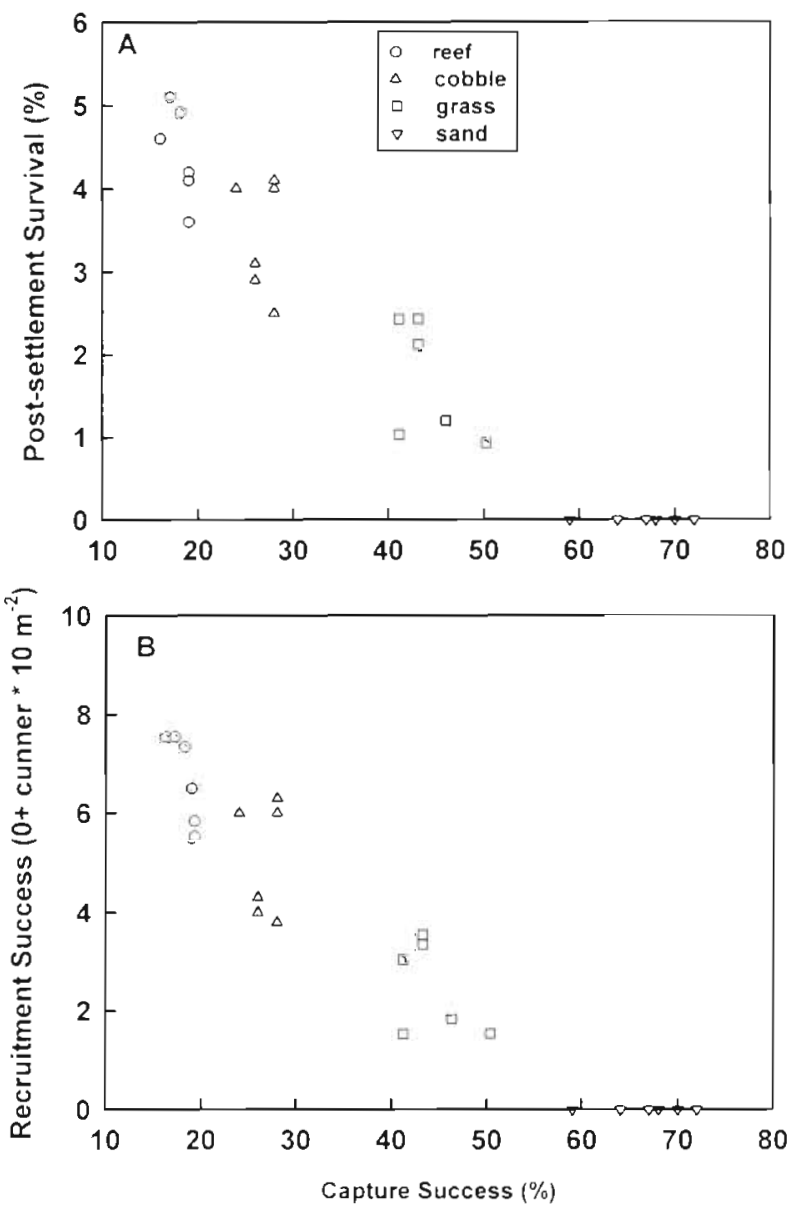

Fig. 4. Tautogolabrus adspersus. Relationship of capture success of coltid predators Hemitripterus americanus, $M y$ oxocephalus octodecemspinosus and $M$. aeneus feeding on $0+$ cunner, to (A) post-settlement survival of cunner and (B) recruitment success of cunner. Survival is estimated as the percentage of total cumulative settlement to a transect that remained at the end of November Recruitment success is estimated as the number of $0+$ cunner on each transect remaining at the end of November

\section{DISCUSSION}

\section{Relationship of settlement to population size}

In this study, juvenile cunner did not demonstrate any preference for habitat type at settlement, and the spatially uniform pattern of settlement was in no way related to the spatial pattern of post-recruitment juvenile or adult density. In contrast to patterns of settlement, density of juvenile cunner 8 to $12 \mathrm{wk}$ after settlement varied greatly between habitat types. The processes regulating among-habitat distributions of cunner must therefore occur post-settlement, with differential survival rather than differential settlement leading to the observed patterns of density.
The relative importance of settlement and post-settlement processes in determining fish-habitat associations is unknown for most species (Jones 1991). Sale et al. (1984) clearly demonstrated that several species of coral reef fish settle preferentially to specific microhabitats, and suggested that spatial variation in microhabitat structure may result in spatial variation in settlement and subsequent recruitment. However, habitat type may influence post-settlement processes to either reinforce or alter spatial patterns established at settlement. For example, the damselfish Pomacentrus amboinensis settles preferentially in deeper lagoonal waters, where its subsequent growth rate and survival is higher than in shallow water (Jones 1986). In contrast, the blennoid fish Forsterygion varium settled uniformly among habitat types differing in structural complexity, but exhibited extreme differences in subsequent survival and density, which were much higher in more complex habitats (Connell \& Jones 1991). This pattern is identical to that exhibited by juvenile cunner in this study. As with F. varium, among-habitat variation in the survival of juvenile cunner dramatically altered patterns of settlement.

\section{Influence of habitat structure and predation on juvenile demography}

Recruitment success varied significantly among habitats and was higher in more complex habitats. These results suggest that juvenile cunner in St. Margaret's Bay are limited by the availability of shelter sites, and that suitable nursery habitats for juvenile cunner should provide an abundance of refugia. Recruitment success was positively correlated with adult density; this has been suggested as evidence for facilitation of settlement or post-settlement survival by resident conspecifics (Sweatman 1985, 1988, Jones 1987. Forrester 1990). However, since substrate complexity, post-settlement survival, post-recruitment juvenile density and adult density were intercorrelated, it seems more likely that the correlation between juvenile and adult cunner simply reflects the greater suitability of complex substrates as cunner habitat (see also Connell $\&$ Jones 1991). Few large adult cunner (age $3+$ or older) were present at the study sites. This may reflect a decrease in dependence of large cunner on the shelter offered by nearshore complex habitats (Pottle \& Green 1979), presumably due to a decrease in their vulnerability to predation. Thus, while the presence of older, larger cunner may not point to a suitable habitat for cumner recruits (Levin 1993), the presence of age $1+$ and $2+$ fish may be a more reliable indicator.

The existence of a positive relationship between the density of juvenile fish and habitat complexity has 
been considered evidence for space-limitation, i.e intraspecific competition for limited shelter sites (e.g. Shulman 1984). In this study, predation efficiency of cottid predators decreased with increasing habitat complexity. Tupper \& Boutilier (1995c) also found that predation efficiency of cottids feeding on young-ofyear Atlantic cod Gadus morhua was inversely related to habitat complexity, and similar results were observed for predation on amphipods by yellow perch Perca flavescens and ruffe Gymnocephalus cernuus (Mattila 1992). Gotcietas \& Brown (1993) found that young-of-year cod $G$. morhua kept in aquaria, selected more complex substrates in the presence of a predator. Thus, the relationship between habitat complexity and population density need not be explained by competition for living space, but can instead be attributed to differential predation among habitat types. It should be noted that although predation efficiency decreased in more complex habitats, a very high predator density in more complex habitats might still lead to predation mortality being higher in those habitats. In St. Margaret's Bay, predator density was highest on reef and cobble substrates, but the density was not sufficiently high to overcome the low capture rates. As a result, the total mortality attributed to predation remained inversely related to habitat complexity.

Mattila (1992) suggests that predation efficiency is not automatically reduced by a high level of habitat complexity per se; the prey must be able to utilize that complexity as an effective shelter. In the present study, seagrass beds could conceivably provide the greatest complexity of the 4 habitats, if the vertical area of each blade of grass were measured. However, young-ofyear cunner did not utilize seagrass blades as shelterthey preferred rocks, empty scallop shells, and other debris found within the seagrass beds. Considering the rapid post-settlement growth rates of young-of-year cunner, it seems likely that they essentially outgrow seagrass blades as a suitable refuge soon after settlement.

Connell \& Jones (1991) hypothesized that the lack of variation among habitats in settlement of Forsterygion varium may be due to settlement-sized fish finding shelter in a wide range of habitats, while variation among habitats in post-settlement mortality may arise from newly settled fish outgrowing suitable shelter in low-complexity habitats. Our findings for cunner support this hypothesis. If cunner, at their smallest sizes (10 to $15 \mathrm{~mm}$ ), can utilize all habitats more or less equally, variation in settlement to different habitats would not be expected. Patterns of distribution of postrecruitment juvenile cunner would then be determined by habitat-specific predation pressure. This forms the basis for the 'predation hypothesis' (Hixon 1991) which states that post-settlement mortality due to piscivory determines patterns of adult abundance. Lough et al. (1989) offered a similar hypothesis to explain the demography of young-of-year cod Gadus morhua and haddock Melanogrammus aeglefinus on Georges Bank, Atlantic Ocean. They observed that pelagic juvenile gadids were widespread over the bank in June, but that in July, demersal juveniles were found mainly on pebble-gravel beds and were 'poorly represented' on other, less complex sedimentary substrates. They also suggested that, in addition to providing more shelter sites than the other substrates, the pebble-gravel deposits most closely matched the mottled coloring of demersal juvenile cod, making the small fish very difficult to see, and therefore reducing their predation risk. From these results, they concluded that the availability of a complex habitat with reduced predation pressure may be critical to the recruitment success of cod and haddock on Georges Bank.

\section{Growth}

Cunner do not remain active over winter; once the water temperature reaches about $5^{\circ} \mathrm{C}$, they become torpid and rest within refuge sites until the following spring (Dew 1976). Cunner are sexually mature at about 54 to $60 \mathrm{~mm}$ standard length, a size they usually reach as 1-yr-olds (Dew 1976), although Johansen (1925) reported that cunner in Nova Scotia do not reach sexually maturity until age 2 , due to the shorter growing season. However, the shallow nearshore waters of St. Margaret's Bay are notably warmer than Scotian Shelf waters, and age $1+$ fish were often observed spawning at the study sites. Since cunner do not feed or grow over the winter months (Auster 1989), they must approach this size by the start of their first winter in order to join the adult population the following summer. Moreover, many temperate marine fishes rely on stored lipids to survive the winter, and survival is higher in larger individuals (Henderson et al. 1988). Thus, growth rate is crucial to the replenishment of adult cunner populations.

Growth rates of young-of-year cunner in this study were in agreement with published values (Bigelow \& Schroeder 1953); mean growth rate of all recaptured cunner was approximately $0.5 \mathrm{~mm} \mathrm{~d}^{-1}$ Connell \& Jones (1991) have suggested that habitat complexity may influence growth and survival of juvenile fish through increased prey density and prey diversity. Growth rate of young-of-year cunner differed between habitats, but was not related to substrate rugosity per se. However, as discussed in the previous section, the shelter provided by Zostera marina blades was not accounted for by our measure of substrate rugosity. For small prey items, seagrass beds undoubtedly offer the 
greatest habitat complexity. Thus, if habitat complexity is measured relative to prey size rather than predator size, then prey densities and predator growth rates should increase with habitat complexity. For example, Sogard (1992) found that the presence of Zostera marina increased amphipod densities by $64 \%$ and copepod densities by $49 \%$. She reported that growth rates of the tautog Tautoga onitis, another temperate labrid, were higher in vegetated habitats supporting higher prey densities. Tupper \& Boutilier (1995b) found that growth of young-of-year cod Gadus morhua in St. Margaret's Bay was higher in seagrass beds than on rocky reef, cobble or sand bottoms. They also attributed the higher growth rates to greater prey density in the seagrass habitat.

Several researchers have suggested the possibility of trade-offs in habitat utilization by fishes (Gilliam \& Fraser 1987, Werner \& Hall 1988, Gotceitas 1990, Connell \& Jones 1991, Sogard 1992, Walters \& Juanes 1993). Present ecological theory suggests that tish should select for the habitat that maximizes energy gain (growth), while minimizing the risk of mortality (Gilliam \& Fraser 1987, Gotceitas 1990). In this study, young-of-year cunner experienced elevated growth rates in seagrass habitats, but experienced significantly reduced predation risk and mortality on reefs and cobble bottoms. It remains unclear which strategy is more advantageous for young-of-year cunner. Cunner remain torpid without feeding over the winter months and rely on stored lipids to survive the winter (Dew 1976). Survival of this and other species in northern climates is generally correlated with body size, as larger individuals have larger lipid stores on which to draw (Henderson et al. 1988). Tupper \& Boutilier (1995b) demonstrated a similar trade-off in the habitat selection of young-of-year cod (Gadus morhua). They suggested that in terms of replenishing the adult population, reef and cobble habitats might be viewed as supplying larger numbers of small individuals, each with a higher risk of mortality, while seagrass habitat might viewed as supplying fewer numbers of large individuals, each with a higher chance of survival.

Acknowledgements. We thank I. Hunt von Herbing and R. Conrad for their expert assistance in the field. Funding for this project was provided by an operating grant from the Natural Sciences and Engıneering Research Council of Canada (NSERC) program Ocean Production Enhancement Network to R.G.B., and by an NSERC Postgraduate Scholarship and a Dalhousie Graduate Fellowship to M.T

\section{LITERATURE CITED}

Aldenhoven AJ (1986) Local varation in mortality rates and life-expectancy of the coral-reef fish Centropyge bicolor (Pisces, Pomacanthidae). Mar Biol 92:237-244
Auster PJ (1989) Species profiles: life histories and environmental requirements of coastal fishes and invertebrates (North Atlantic and Mid-Atlantic). Tautog and cunner. Biol Rep US Fish Wildl Serv 82(11.105) TR EL-82-4

Behrents K (1987) The influence of shelter availabilıty on recruitment and early juvenile survivorship of Lythrypnus dalli Gilbert (Pisces: Gobiidae). J Exp Mar Biol Ecol 107 $45-59$

Bell JD, Galzin R (1984) Influence of live coral cover on coralreef fish communities. Mar Ecol Prog Sor 15.265-274

Bigelow HB, Schroeder SC (1953) Fishes of the Gulf of Maine, Vol 53. Fish Bull US Fish Wildlf, US Government Printing Office, Washington, DC

Booth DJ, Beretta GA (1994) Seasonal recruitment, habitat associations and survival of pomacentrid reef fish in the US Virgin Islands. Coral Reefs 13:81-89

Breitburg D (1989) Demersal schooling prior to settlement by larvae of the naked goby. Environ Biol Fishes 26:97-103

Breitburg D (1991) Settlement patterns and presettlement behavior of the naked goby, Gobiosoma bosci, a temperate oyster reef fish. Mar Biol 194:221-231

Carr MH (1989) Effects of macroalgal assemblages on the recruitment of temperate zone reef fishes. J Exp Mar Biol Ecol 126:57-76

Carr MH (1991) Habitat selection and recruitment of an assemblage of temperate zone fishes. J Exp Mar Biol Ecol 146:113-137

Carr MH (1994) Effects of macroalgal dynamics on the recruitment of a temperate reef fish. Ecology 75: $1320-1333$

Carr MH, Hixon MA (1995) Predation effects on early postsettlement survivorship of coral-reef fishes. Mar Ecol Prog Ser 124:31-42

Chandler CR, Sanders RR Jr, Landry AM Jr (1985) Effects of three substrate variables on two artificial reef fish communities. Bull Mar Sci 37:129-142

Chao LN (1972) Digestive system and feeding habits of cunner, Tautogolabrus adspersus, a stomachless fish. US Natl Mar Fish Serv Fish Bull 71:565-586

Connell SD, Jones GP (1991) The influence of habitat complexity on postrecruitment processes in a temperate reef fish population. J Exp Mar Biol Ecol 151:271-294

Dew CB (1976) A contribution to the life history of the cunner, Tautogolabrus adspersus, in Fishers Island Sound, Connecticut. Chesapeake Sci 17:101-113

Doherty PJ (1983) Tropical territorial damselfishes: is density limited by aggression or recruitment? Ecology 64:176-190

Doherty PJ, Fowler AJ (1994) An empirical test of recruitment limitation in a coral reef fish. Science 263:935-939

Eckert GJ (1985) Settlement of coral reef fishes to natural substrata at different depths. Proc 5th Int Coral Reef Symp. Tahiti 5:131-139

Forrester GE (1990) Factors influencing the juvenile demography of a coral reef fish. Ecology 71:1666-1681

Gaines S, Roughgarden J (1985) Larval. settlement rate: a leading determination of structure in an ecological community of the marine intertidal zone. Proc Natl Acad Sci USA 82:3707-3711

Gilliam JF, Fraser DF (1987) Habitat selection under predation hazard: test of a model with foraging minnows. Ecology 68:1856-1862

Gotceitas V (1990) Foraging and predator avoidance: a test of a patch choice model with juvenile bluegill sunfish. Oecologia 83:346-351

Gotceitas V, Brown JA (1993) Substrate selection by juvenile Atlantic cod (Gadus morhua): effects of predation risk. Oecologia 93:31-37 
Henderson PA, Holmes RHA, Bamber RN (1988) Size-selective overwintering mortality in the sand smelt, Atherina boyeri Risso, and its role in population regulation. J Fish Biol 33:221-233

Hixon MA (1991) Predation as a process structuring coral-reef fish communities, In: Sale PF (ed) The ecology of fishes on coral reefs. Academic Press, San Diego, p 475-508

Hixon MA, Beets JP (1989) Shelter characteristics and Caribbean fish assemblages: experiments with artificial reefs. Bull Mar Sci 44:666-680

Hixon MA, Beets JP (1993) Predation, prey refuges and the structure of coral-reef fish assemblages. Ecol Monogr 63: 77-101

Holbrook SJ, Schmidt RJ (1988) The combined effects of predation risk and food reward on patch selection. Ecology 69:125-134

Houde E (1987) Fish early life dynamics and recruitment variability. Am Fish Soc Symp Ser 2:17-29

Hughes TP (1990) Recruitment limitation, mortality, and population regulation in open systems: a case study. Ecology $71: 12-20$

Johansen $F$ (1925) Natural history of the cunner. Contrib Can Biol 2:423-468

Jones GP (1984) The influence of habitat and behavioural interactions on the local distribution of the wrasse Pseudolabrus celıdotus. Environ Biol Fishes 10:43-58

Jones GP (1986) Food availability affects growth in a coral reef fish. Oecologia 70:136-139

Jones GP (1987) Competitive interactions among adults and juveniles in a coral reef fish. Ecology 68:1534-1547

Jones GP (1990) The importance of recruitment to the dynamics of a coral reef fish population. Ecology 71:1691-1698

Jones GP (1991) Postrecrutment processes in the ecology of coral reef fish populations: a multifactorial perspective. In Sale PF (ed) The ecology of fishes on coral reefs. Academic Press, San Diego, p 294-328

Kaufman L, Ebersole J, Beets J, Mclvor CC (1992) A key phase in the recruitment dynamics of coral reef fishes: post-settlement transition. Environ Biol Fishes 34:109-118

Kingsford MJ, Wolanski $E$, Choat JH (1991) Influence of tidally induced fronts and Langmuir circulations on distribution and movements of presettlement fishes around a coral reef. Mar Biol 109:167-180

Leis JM (1991) The pelagic stage of reef fishes: the larval biology of coral reef fishes. In: Sale PF (ed) The ecology of fishes on coral reefs. Academic Press, San Diego, p $183-230$

Levin PS (1991) Effects of microhabitat on recruatment varation in a Gulf of Maine reef fish. Mar Ecol Prog Ser 75 $183-189$

Levin PS (1993) Habitat structure, conspecufic presence and spatial variation in the recruitment of a temperate reef fish. Oecologia 94:176-185

Levin PS (1994a) Fine-scale temporal variation in recruitment of a temperate demersal fish: the importance of settlement vs post-settlement loss. Oecologia 97:124-133

Levin PS (1994b) Small-scale recruitment variation in a temperate fish: the roles of macrophytes and food supply. Environ Biol Fishes 40:271-281

Lough RG, Valentine PC, Potter DC, Auditore PJ, Bolz GZ, Neilson J, Perry RI (1989) Ecology and distribution of juvenile cod and haddock in I teldtion to sediment type and bottom currents on eastern (icorges Bank. Mar Ecol Prog Ser $56: 1-12$

Luckhurst BE, Luckhurst K (1977) Recruitment patterns of coral reef fishes on the fringing reefs of Curaçao, Netherlands Antılles. Can J Zool 55:681-689
Mattlla J (1992) The effect of habitat complexity on predation efficiency of perch Perca fluviatilis L. and ruffe Gymnocephalus cernuus (L.). J Exp Mar Biol Ecol 157:55-67

Post JR, Evans DO (1989) Experimental evidence of sizedependent predation mortality in juvenile yellow perch. Can J Zool 67:521-523

Pottle RA, Green JM (1979) Field observations on the reproductive behavior of the cunner, Tautogolabrus adspersus (Walbaum), in Newfoundland. Can J Zool 59:1582-1585

Roberts CM, Ormond RG (1987) Habitat complexity and coral reef fish diversity and abundance on Red Sea fringing reefs. Mar Ecol Prog Ser 41:1-8

Robertson DR (1988a) Abundances of surgeonfishes on patch-reefs in Caribbean Panama: due to settlement, or post-settlement events? Mar Biol 97:495-501

Robertson DR (1988b) Settlement and population dynamics of Abudefduf saxatilis on patch reefs in Carıbean Panama. Proc 6th Int Coral Reef Symp, Townsville 2:839-843

Sale PF (1977) Maintenance of high diversity in coral reef fish communities. Am Nat 111:337-359

Sale PF, Douglas WA, Doherty PJ (1984) Choice of microhabitats by coral reef fushes at settlement. Coral Reefs 3:91-99

Sale PF, Ferrell DJ (1988) Early survivorship of juvenile coral reef fishes. Coral Reefs 7:117-124

Scott WB, Scott MG (1988) Atlantic fishes of Canada. Can Bull Fish Aquat Sci 219:1-731

Shenker JM, Maddox ED, Wishinski E, Pearl A, Thorrold SR, Smith N (1993) Onshore transport of settlement stage Nassau grouper (Epinephalus striatus) and other fishes in Exuma Sound, Bahamas. Mar Ecol Prog Ser 98:31-43

Shulman MJ (1984) Resource limitation and recruitment patterns in a coral reef tısh assemblage. J Exp Mar Biol Ecol $74: 85-109$

Shulman MJ (1985) Recruitment of coral reef fishes: effects of distribution of predators and shelter Ecology 66: 1056-1066

Shulman MJ, Ogden JC (1987) What controls tropical reef populations: recruitment or benthic mortality? An example in the Caribbean reef fish Haemulon flavolineatum. Mar Ecol Prog Ser 39:233-242

Snedecor GW, Cochran WG (1981) Statistical methods, 7th edn. Iowa State University Press, Ames

Sogard S (1992) Variability in growth rates of juvenile fishes in different estuarine habitats. Mar Ecol Prog Ser 85:35-53

Sweatman $\mathrm{H}$ (1985) The influence of adults of some coral reef fishes on larval recruitment. Ecol Monogr 55:469-485

Sweatman H (1988) Field evidence that settling coral reef fish larvae detect resident fishes using dissolved chemical cues. J Exp Mar Biol Ecol 124:163-174

Thresher RE (1983) Environmental correlates of the distribution of planktivorous fishes in the One Tree Reef lagoon. Mar Ecol Prog Ser 10:137-145

Tolimueri $N$ (1995) Effects of microhabitat characteristics on the settlement and recruitment of a coral reef fish at two spatial scales. Oecologia 102:52-63

Tupper M (1994) Settlement and post-settlement processes in the population regulation of a temperate reef fish: the role of energy. PhD thesıs, Dalhousie University, Halifax

Tupper M, Boutilier RG (1995a) Size and priority influence growth and competitive success of newly settled Atlantic cod. Mar Ecol Prog Ser 118:295-300

Tupper M. Boutilier RG (1995b) Effects of habitat on settlement, growth and post-settlement mortality of age $0_{+}$ Atlantic cod (Gadus morhua). Can J Fish Aquat Sci 52: $1834-1841$

Tupper M, Boutilier RG (1995c) Effects of conspecific density on settlement, growth and post-settlement survival of a 
temperate reef fısh. J Exp Mar Bıol Ecol 191:209-222

Underwood A.J, Fairweather PG (1989) Supply-side ecology and benthic marine assemblages. Trends Ecol Evol 4:16-19

Walsh WJ (1985) Reef fish community dynamics on small artificial reefs: the influence of isolation, habitat, structure, and biogeography. Bull Mar Sci 39:357-376

Walters CJ, Juanes F (1993) Recruitment limitation as a consequence of natural selection for use of restricted feeding

This article was submitted to the editor habitats and predation risk taking by juvenile fishes. Can J Fish Aquat Sci 50:2058-2070

Werner EE, Hall DJ (1988) Ontogenetic habitat shifts; in bluegill: the foraging rate-predation risk trade-off. Ecology $69: 1352-1366$

Whoriskey FG (1983) Intertidal feeding and refuging by cunners, Tautogolabrus adspersus (Labridae). US Fish Bull 81: $426-428$

Manuscript first received: July 20, 1994

Revised version accepted: January 14, 1997 